J. of Modern African Studies, 56, 2 (2018), pp. 217-243 C Cambridge University Press 2018. This is an Open Access article, distributed under the terms of the Creative Commons Attribution licence (http://creativecommons.org/licenses/by/4.o/), which permits unrestricted re-use, distribution, and reproduction in any medium, provided the original work is properly cited.

doi:10.1017/SoO22278X18000186

\title{
Economic growth, rural assets and prosperity: exploring the implications of a 20-year record of asset growth in Tanzania*
}

\author{
Dan Brockington and Olivia Howland \\ Sheffield Institute for International Development, University of Sheffield, \\ Sheffield $S_{I O} 2 T N$, United Kingdom
}

Emails: d.brockington@sheffield.ac.uk and oliviahowland@googlemail.com

Vesa-Matti Loiske

Södertörn University, Flemingsberg, I 4 I 89 Huddinge, Sweden

Email: vesa-matti.loiske@sh.se

and

Moses Mnzava And Christine Noe

University of Dar es Salaam, P.O. Box 35049, Dar es Salaam, Tanzania

Emails: moses.emanuel@gmail.com and cnpallangyo@gmail.com

\section{A B S T R A C T}

Measures of poverty based on consumption suggest that recent economic growth in many African countries has not been inclusive, particularly in rural areas. We argue that measures of poverty using assets may provide a different

* The authors gratefully acknowledge the support of the DfID ESRC Growth Research Programme (ES/Lo12413/2) which has funded this research project and of the Research Council of Norway which has supported this work through the Greenmentality project. We are grateful to the University of Manchester for supporting Brockington's sabbatical research, to two anonymous reviewers for their incisive and supportive comments on an earlier MS and to the residents of Gitting and Gocho for answering our questions and discussing the findings with us. 
picture. We present data based on recent re-surveys of Tanzanian households first visited in the early $1990 \mathrm{os}$. These demonstrate a marked increase in prosperity from high levels of poverty. It does not, however, follow that these improvements derive from GDP growth. We consider the implications of this research for further explorations of the relationship between economic growth and agricultural policy in rural areas.

I N T R O D U C T I O N

Rapid economic growth is transforming many African economies (Radelet 2010). Sustained high rates of growth (despite downturns and austerity elsewhere in the world), macro-economic stability, relatively low inflation, and growing investment and infrastructural development are seeing numerous countries become more prosperous. Some observers are celebrating a rising continent, that will be known for its growth, peace and stability (Chuhan-Pole \& Angwafo 2011).

Whether this growth is inclusive and pro-poor is less obvious (Barrett 2011 ). The highly visible prosperity in urban areas that characterises current economic growth can conceal persistent poverty in rural areas. Indeed, observers fear that some forms of investment may cause more problems if that investment is accompanied by land loss (Borras et al. 2011; Benjaminsen \& Bryceson 2012; Fairhead et al. 2012; Gardner 2012 ). Others observe that growth at the national scale is accompanied by rural differentiation and class formation in villages that maintain significant deprivation (Mueller 2011 ). Dercon's call for more longer-term insights into the fortunes of rural households during periods of growth remains as relevant as ever (Dercon 2006).

In this article we explore the relationship between economic growth and rural poverty in Tanzania. This country presents an apposite case study, in that it has enjoyed substantial growth in the last 20 years, yet is still characterised by high levels of rural poverty. However, understanding the dynamics of rural poverty is difficult because of the paucity of data available. Our contention is that by critically examining existing sources, and by exploring new data, we make it possible to tell more stories about poverty and prosperity in rural areas in Tanzania. More specifically, we make some forms of rural prosperity more visible than they currently are. We also suggest, however, that it may not be possible to connect this improved wellbeing to economic growth as measured in GDP.

The new data we examine here concern long-term trends in asset use and ownership by rural people. Attention to assets is important because they feature so prominently in local definitions of wealth and local 
investment strategies. Yet common measures of poverty, and in particular poverty lines based on basic baskets of consumption, do not include assets.

We proceed as follows. First, we outline the debates surrounding Tanzania's growth and its inclusivity - whether or not it has benefitted the poorer members of Tanzanian society. Second, we critically examine the data which are used to argue that poverty has not declined. We then introduce the methods which we used, which entailed revisiting families who were previously surveyed over 20 years ago. Fourth, we present the findings which show an increase in prosperity according to local measures of wealth, which hinge on assets. This is intriguing and we suggest further lines of enquiry that explore its implications in the discussion and conclusion.

\section{TANZANIA - INCLUSIVE GROWTH?}

Many observers are quick to praise Tanzania' economic success over the last 20 years (Edwards 2014; Adam et al. 2017). According to Edwards, in Nyerere's last years in power, the country was suffering from stagnant agriculture and manufacturing, productivity in 'free fall', and a 'skyrocketing' trade deficit (Edwards 2014: 81). The broad social vision that drove his policies (such as free universal primary education) were suffering from a basic absence of state funds. Since then, with reforms and structural adjustment, the economy has been transformed. Nord and colleagues summarise the changes as a 'remarkable turnaround', compared to the want and scarcity that characterised the country in the 1980 os. Now there is low inflation, a 'buoyant' economy which has averaged $7 \%$ annual growth, real per capita income has risen $50 \%$ and poverty is 'heading downwards' (Nord et al. 2009: 1). Robinson and colleagues describe a period of accelerated growth since 1996 that has seen macro-economic stability and increased public spending (Robinson et al. 2011).

But there is wariness as to whether this growth has been inclusive. In particular, there is concern that the benefits of growth are not being experienced by the rural poor. Robinson and colleagues note that agriculture has not really contributed to this growth, which is a "cause of concern' given that agriculture is the economic mainstay of rural areas where most people, and most of the country's poor people, live (Robinson et al. 2011: 26-7).

For the most severe critics, the deprivation in rural areas despite years of economic growth is particularly damning. Mashindano and colleagues compared change in poverty statistics using Household Budget 
Survey (HBS) data with GDP growth data. They conclude that there has been substantial economic growth, but that this growth has not reached the poor; if anything it has passed them by (Mashindano et al. 2013: $126)$. The gap is particularly stark after 2000 when GDP growth outstripped population growth considerably, but was not matched by a commensurate fall in rural poverty. Edwards, using the same data, notes that poverty decline has been far slower in Tanzania than in other countries (Edwards 2014: 251). Arndt and colleagues also observe that growth in GDP from 1990 to 2007 , but slow decline in poverty over the same period, was a conundrum (Arndt et al. 2017). The indications are that most households (and particularly most rural households) were not benefitting from the continued economic growth the country was experiencing in this period.

The poor performance of agriculture, which has not seen significant increases in productivity, and the consequent inability of smallholders to become wealthier in appreciable numbers, is particularly sobering. This appears partly to be due to the low productivity of smallholders in absolute terms - they cannot produce enough to prosper (Jayne et al. 2010; Bryngelsson et al. 2012). Case studies of social change in agrarian contexts suggest that rural labour markets seems to be fuelling differentiation within villages that benefit only a minority (Mueller 201 1; Greco 2015).

More detailed analyses of the 2007 HBS data report that there are signs that agricultural livelihoods are proving particularly unprofitable (Hoogeveen \& Ruhinduka 2009). These analyses suggest that Tanzanians were diversifying out of agriculture in order to improve their wealth, and investment in agricultural assets (livestock, ploughs and hoes) declined between 2001 and 2007. Indeed the analysts go so far as to state that 'it is difficult to make a decent living out of agriculture' (p. 29). ${ }^{1}$

More recent HBS analyses, which use an altered method for collecting consumption data and constructing poverty lines, suggest that there has been a reduction in poverty in recent years (since 2007), and that growth has become more inclusive (World Bank 2015). But the fact remains that for around two decades since 1990 Tanzania's economic growth was not sufficiently inclusive, and that rural areas and most of the population, appeared to be particularly badly off. Many Tanzanians have only been able to enjoy their country's growing prosperity vicariously. Some authors conclude that the important question to consider now is how and why growth in Tanzania in the 1990 and 2000 failed to reduce poverty (Mashindano \& Shepherd 2013: 3). 
However, before we address Mashindano and Shepherd's question, we must take another, closer, look at the data, for when we do so the story becomes more complicated. There is evidence that, if we consider rural families' investment in assets, then the rural economy is more diverse, and has more potential for prosperity, than it first appears. That proposition is the concern of the present paper.

We believe that assets deserve more careful consideration for three reasons. First, we show that the data used to construct poverty lines do not count changes in assets. Second, assets matter a great deal for rural livelihoods. Third, there is some evidence that exploring change in assets will capture important dynamics not currently recognised in poverty line data.

Poverty lines are constructed from HBS data using measures of consumption. They are calculated on the basis of how much money people spend day-to-day.

The basis for assessing income poverty is a measure of households' consumption expenditure ... This is compared with a poverty line, which represents the cost of a basic basket of consumption. Households that fall below the poverty line are poor; individuals are classed as poor if they live in a poor household. (United Republic of Tanzania 2009: 47)

However, not all expenditure is included in this measure of household consumption: 'the measure used in the poverty analysis excludes large durable items, which are rare purchases and are not typical of the household's usual consumption level' (United Republic of Tanzania 2009:47). There are good reasons for this omission. Purchasing an expensive item in the week of the survey would make a family look wealthy, with weekly expenditure of hundreds, if not thousands of dollars. These rare items have to be omitted as outliers. But this means that the method cannot capture investment in assets. The purchase of a car, motorbike or house has to be excluded from the 'basic basket'. Thus a poor family which has successfully saved and purchased a large durable item (such as a plough) from which it then earns an income, would appear no richer in an HBS survey. ${ }^{2}$ Similarly a well-endowed family living frugally, but supporting its children through education, or living in a good house, would look poor as these forms of expenditure are specifically excluded: 'Expenditure on medical care, education, water, telecommunications and postage are also excluded ... Rent and imputed rent were also excluded because of the poor reporting of the latter' (United Republic of Tanzania 2009: 47). 
These exclusions present a problem because they omit important forms of behaviour and expenditure that concern assets (Johnston \& Abreu 2016). In part they matter because assets can be valuable. For example the IGAD initiative has re-valued the contribution of livestock to rural economies in Kenya, Uganda, Ethiopia and the Sudan, increasing their worth by $37 \%$ (over US\$23 billion). Official figures typically dramatically underestimate the value of milk production and manure, nor do they capture the value of livestock as draught animals, or as a form of savings and financial services (Behnke 2010; Behnke \& Metaferia 2011; Behnke \& Muthami 2011; Behnke \& Nakirya 2012; Behnke \& Osman 2012).3

Assets are not just undervalued by states, they are featured significantly in local definitions of wealth and poverty. These definitions tend to hinge on ownership of, or at least the ability to use, assets like land, livestock and small businesses (see Table I). A good life is manifest in a fine house and furniture more than measures of consumption. Poverty researchers have frequently observed this phenomenon (Shaffer 2013a). The 'Voices of the Poor' study undertaken by the World Bank found that assets were particularly important for the poor's own understanding of their poverty and desired wealth (reported in Meinzen-Dick et al. 2011).

In rural areas assets are a useful means of storing and saving wealth in agricultural societies where income is lumpy and infrequent because it depends on harvests. Injections of cash will be targeted at acquiring assets rather than everyday consumption. This is captured by this focus group statement:

We get money seasonally. This means for all of us here there are those who have earned three million shillings, or two million shillings, but if right now you were to ask one of us here to lend you a small amount of money she would tell you I haven't even got a cent [laughter] ... if you want to borrow a million shillings she will give it, but go to them in November and ask to borrow 200,00o to deal with a problem and they will tell you I have nothing, I have bought a TV, I've bought a plot, I've bought bricks. 4

The statement reflects a wider literature which shows that a classic response of households that are becoming wealthier is to invest in their assets, rather than in, for example, improving their diet and basic baskets of consumption (see for example Scott 2010). Assets provide for the long-term future of households, which is why owning assets is a good indication of long-term prospects, and selling assets a sign of impending problems (cf. De Waal 1989). They make families more resilient to shocks and problems, and better able to prosper 
TABLE I.

Wealth stratification systems for Tanzania

\begin{tabular}{|c|c|c|}
\hline $\begin{array}{l}\text { Wealth } \\
\text { Group }\end{array}$ & $\begin{array}{l}\text { Wealth Group Characteristics } \\
\text { Loiske (1995) }\end{array}$ & $\begin{array}{l}\text { Wealth Group Characteristics } \\
\text { Higgins and Da Corta (2013) }\end{array}$ \\
\hline \multirow[t]{2}{*}{1} & Immensely Rich. & Rich (tajiri). \\
\hline & Knows no barriers, has cars, lorries etc. & Significant assets and local power. \\
\hline \multirow[t]{2}{*}{2} & Very Rich. & Involved in large-scale or employment of labour. \\
\hline & $\begin{array}{l}\text { Many cattle and much land; owns a tractor but not a lorry. Has } \\
\text { businesses and land in towns. }\end{array}$ & $\begin{array}{l}\text { Owns large-scale non-farm assets. } \\
\text { May lend money. }\end{array}$ \\
\hline \multirow[t]{2}{*}{3} & Rich. & \\
\hline & Employs many vibarua; has many cattle. Has businesses. & \\
\hline \multirow[t]{3}{*}{4} & Above Average farmer. & Resilient (tajiri kiasi, mwenye uwezo). \\
\hline & $\begin{array}{l}\text { Some cattle; farms their own land and uses vibarua work } \\
\text { occasionally. }\end{array}$ & $\begin{array}{l}\text { Sufficient capacity (e.g. assets, social networks) to prevent significant downward mobility relative } \\
\text { to overall productive wealth. }\end{array}$ \\
\hline & & May employ small amounts of labour on the farm or be involved in small-scale trade. \\
\hline \multirow{11}{*}{5} & Average farmer. & Vulnerable but not poor (tete ila siyo maskini). \\
\hline & A few cattle, farms their own land without using vibarua work. & More productive assets which take the family through the year. \\
\hline & & During good times can save. \\
\hline & & During bad times will reduce family consumption. \\
\hline & & Vulnerable to downward mobility with a significant shock. \\
\hline & & Poor (maskini). \\
\hline & & Access to limited productive assets (land and livestock). \\
\hline & & $\begin{array}{l}\text { Cannot earn enough from farming or trade to take family provisioning through the whole year so will } \\
\text { reduce family food consumption. }\end{array}$ \\
\hline & & Cannot save much in good years. \\
\hline & & Must sell assets in order to cope in a crisis. \\
\hline & & Vulnerable to downward mobility to 'very poor' category but not to 'destitute' category. \\
\hline \multirow[t]{2}{*}{6} & Poor & Very Poor (maskini sana). \\
\hline & $\begin{array}{l}\text { Rents land out to others; depends on casual vibarua work for } \\
\text { daily needs; few if any livestock. }\end{array}$ & $\begin{array}{l}\text { No clear livelihood source; no significant productive assets; dependent on selling labour and/or } \\
\text { scavenging; erratic income and food access; very vulnerable to becoming destitute with shock. }\end{array}$ \\
\hline \multirow[t]{2}{*}{7} & Extremely poor & Destitute (maskini hohehahe). \\
\hline & $\begin{array}{l}\text { Unable to get work easily; hard to rent their land out to others; } \\
\text { suffering from alcoholism and/or illness. }\end{array}$ & Depends on others for basic needs; Cannot work; tends to be socially excluded. \\
\hline
\end{tabular}

Vibarua work refers to casual labour.

Source: Loiske (1995), Higgins \& Da Corta (2013: 17). 
from good fortune. As Carter \& Lybbert (2012) have found in Burkina Faso, asset wealth can demarcate different forms of behaviour in times of stress, with wealthier families able to sell assets in order to maintain their levels of consumption, whereas asset-poor families reduced consumption in order to conserve assets. Not counting assets, as occurs when poverty lines are constructed, is therefore problematic because it misses important investments, goals and the meaning of a prosperous life in many African rural areas.

A final reason to look carefully at assets is that there is a body of literature which suggests they provide insight into important trends, and indicate more prosperity than hitherto realised. Arndt and colleagues found that indices of education, shelter and water provision had improved in Tanzania from 1990 (Arndt et al. 2017). More controversially, Alwyn Young examined the records of change in assets in the Demographic and Health Surveys ( 135 surveys across $5^{6}$ countries over 20 years) to construct asset indices to suggest that there has in fact been an 'African Growth Miracle' which is unrecognised by current data based on consumption (Young 2012). Young's work covered only unproductive assets, but he concluded that material consumption had been rising at $3 \cdot 5^{-4}$ times the rates recognised in other sources (see also Sahn \& Stifel 2000).

Young's work has generated considerable controversy. Harttgen et al. (2013) argue that the continental conclusion is based on inappropriate extrapolation from prospering countries. Furthermore there may be a problem of 'asset drift', meaning that 'assets accumulate at the household level even in the absence of income growth' (Harttgen et al. 2013: $\mathrm{S}_{42}$ ). They also observe that there is a poor correlation between assets and income. These arguments still leave substantial elements of Young's thesis intact. If the continental picture is exaggerated it still could be true for individual countries. Well-being may improve with asset drift, even if income does not (through, for example, reduced exposure to risk and unexpected misfortune). Finally, while Harttgen and colleagues are quite right to complain that assets are poorly correlated with consumption, that does not mean that consumption is the 'true' measure of economic performance. What matters more is how well both measures correlate with prosperity and well-being. That is harder to determine.

Johnston \& Abreu's (2016) response to Young's work suggests that there may well be changes visible through exploring assets, but that we have to be careful as to the scale of the analysis that we use. They welcome the improving welfare that Young documented (lower death 
rates, more education as well as more physical assets) and note that it is clear that the asset data tell us a reliable story about the accumulation of assets by many people in many African countries' (p. 20). But they offered a number of important correctives on the use of asset indices. Assets are used to construct asset indices because it is believed that assets correlate well with wealth. However, the reasons behind asset acquisition are multiple, and are not merely determined by wealth. Asset indices, like those Young constructed, can become particularly problematic when used for comparison over long time periods, or large geographic scales.

Yet, if national scale asset indices (and international comparison from them) are problematic then this point also means that they can be used with more power locally. Where assets are used to construct local indices of well-being, wealth and poverty and where they are grounded in local understandings of the value of assets, they can be revealing. Observing assets could be a useful means of exploring the variety of stories that can be told about rural societies and economic growth in diverse African countries. If assets are an important part of rural livelihoods then it may be premature to conclude, as Mashindano and others have done, that economic growth in Tanzania has excluded the poor. The measure of poverty they were using for their sober assessment did not look at change in assets.

Taking a critical look at data on economic growth in Tanzania therefore presents a problem. On the one hand, the vibrant economic growth of the last 20 years appears to have been a restricted urban phenomenon which is simply not enjoyed by the bulk of the population, the rural poor, who most need to see some change. On the other hand, the measures which raise this alarm are in themselves incomplete.

Good panel data, which are so useful in tracking poverty dynamics and which might be able to tackle this dilemma, are scarce (Baulch \& Hoddinott 2000; Dercon \& Shapiro 2007; Dercon et al. 2009; Baulch $2011)$. Clearly other data, and methods, are required in order to gain some insights into livelihood and prosperity dynamics in the rural economy. That is the challenge which we have tried to take up in this paper. We present first the method we used and then the findings it yielded.

\section{E T H O D S}

We have taken a one-off survey conducted in the early 1990 and turned it into a longitudinal survey by re-surveying the same households. This 
technique has been used before in the Kagera Health and Development Survey, which traced over 2,700 families in 2004 when seeking to reinterview 912 families that had participated in a survey in the early 1990 (De Weerdt 2010; Beegle et al. 2011). It is similar to methods which ask respondents to reconstruct change over time from the present (turning survey data 'upside down', as described by Dercon \& Shapiro (2007: 30)), except that it does not rely on those memories for its baseline. The baseline is provided by the first survey. This gives it an advantage as recall can suffer from rose-tints and inaccuracy - a risk, for all its insights, in the 'stages of progress' method (Krishna et al. 2004; Krishna 2006, 2010). We rely instead on actual observations recorded some 20 years ago.

We have used data from a survey undertaken in Gitting, in Hanang District, Manyara Region, in north-central Tanzania.5 This village was surveyed by Loiske between 1991 and 1994 as part of his PhD (Loiske 1995). Loiske's first step was to explore the distribution of wealth in his study area. His unit of analysis was the 'household', which was defined as any homestead registered on the village lists. ${ }^{6}$ The categorisation system of wealth that he used, and its accuracy, is fundamental to the argument of this paper and it is important to consider it carefully.

Loiske's informants divided households into seven groups - two poor, two average and three varieties of wealthy farmer. The criteria they used are shown in Table I. From this table it should be instantly apparent that the local classification of wealth was fundamentally a measure of use and ownership of assets, as has been observed elsewhere. Lest this ranking scheme should now appear dated, we have included for comparison the criteria used in the work of Higgins \& Da Corta (2013), for research in the same country. With some differences they match reasonably well. The importance of assets in local measure of prosperity in rural Tanzania is enduring.

Loiske established these wealth categories, and the distribution of households within them, with some rigour. He began by taking a list of all households in the village which had been allocated land in the villagisation operation. He then arranged for 18 separate key informants to rank these households in order of wealth. All the key informants were men, aged between 25 and 45, and were mostly themselves middleranking farmers; 609 households were ranked in this way. From this ranking exercise emerged the seven categories of wealth which are shown in Table I. Loiske then randomly selected $20 \%$ of the households of each wealth group (122), of which he was able to interview and/or visit 94 for his research. 
Brockington revisited the original families in 2013 to explore how livelihoods had changed, and what might explain these changes. Of the 94 households Loiske surveyed we were able to identify 86 , of which Brockington visited 77. This was part of a year of sabbatical research during which he was based in the neighbouring village of Miaskron. He conducted his work in part with one of Loiske's former research assistants, and with the assistance of a former village executive officer, who was identified by the village leadership as a useful assistant, and who was old enough to remember the condition of families when Loiske was conducting the research. Interviews were conducted in a mixture of Swahili and Iraqw, which sometimes required translation into Swahili.

'Household' surveys should ring alarm bells among Africanist researchers who are familiar with longstanding critiques of all that households can conceal (Guyer 1981; Moock 1986). Our reasons for using this social unit are complex, and discussed at length elsewhere (Brockington et al. 2017). Suffice to say here that we hope we do not use 'households' in the cavalier way that has too often characterised social surveys (Randall et al. 2011; Randall \& Coast 2015). Rather we explore the changing fortunes of families because these are the appropriate unit of analysis with which to explore trends in assets. Land, livestock and homes in Gitting are not individually owned, but the collective wealth of families. Decisions to sell or rent out any assets are discussed and fought over. Children's education is generally supported by a larger network of relations. It is because we are exploring trends in assets that we need to talk about households and families. For the same reason, we do not attempt to explore changes in fortunes per capita - this would not be socially meaningful in this context. We realise that this method is limited because it risks obscuring changing gender dynamics and intergenerational dynamics.

When meeting with villagers we used a mixture of quantitative and qualitative methods, building on our own experience, and others' (Lawson et al. 2003; Adato et al. 2007; Howe \& McKay 2007; De Weerdt 2010; Shaffer 2013b). The quantitative element re-surveyed households visited earlier, and individuals who have left original households to set up their own homes. The qualitative included a discussion of any changes with household members that become apparent in the resurvey as soon as that survey was completed. In addition we took more detailed oral histories from a representative sub-sample of households to explore important events and changes that have taken place in the intervening years. We took village, crop and economic histories 
(including crop prices) from key informants and district and regional records to build up a picture of the general changes in the area. There were two community-level methods that complemented these tasks. First we undertook a participatory wealth ranking of all households in the village (conducted with the village executive officers, village chairs and sub-village chairs) in order to compare how wealth distributions now compare with the past, and to see whether the households we have resurveyed are still representative of their broader communities. We then shared summaries of findings and changes in public village meetings so that community members could discuss our findings and offer improvements or correction to them.

Gitting should be a good place to be a farmer; it is well-endowed for agriculture. The village is close to Mt Hanang, an extinct volcano some $3,400 \mathrm{~m}$ high. Soils are generally fertile, and Gitting sits on the wetter side of the mountain. It is predominantly composed of the Iraqw ethnic group whose proclivities for agriculture were commended by British colonists (Snyder 2005). Gitting has a slightly unusual history, in that the British supported a select few families in the village to purchase tractors and other implements in an attempt to create an agricultural yeomanry (Raikes 1978). This led to some fabulously wealthy families in the village, farming hundreds of hectares annually (Loiske 1995). All this land was redistributed in the villagisation operation of the early 197 os, with every household receiving four acres each.

The most significant finding from Loiske's research, however, despite these endowments, were the very high levels of poverty that he reported (Table II). This table makes for depressing reading: it shows that over $56 \%$ of households were poor in some way (shaded in dark grey), meaning that they were either destitute (the single largest category), or dependent on uncertain and variable day labour for their livelihood. Indeed it is possible that these levels of poverty are higher than those found in the HBS nationally in 1991/2, for this found less than $40 \%$ of people were below the basic needs poverty line.

The most important difference our re-survey found from past conditions is that most people seem to be much richer. $85 \%$ of families are in the average wealth categories (shaded in light grey in Table II). The destitute are now as rare as the rich, and the poor as a whole constitute just $10 \%$ of people. 
TABLE II.

Social stratification in Gitting in the $1990 \mathrm{~s}$

\begin{tabular}{lcccrc}
\hline \hline & \multicolumn{2}{c}{$1990 \mathrm{r}$} & & \multicolumn{2}{c}{2013} \\
\cline { 2 - 3 } \cline { 5 - 6 } Wealth Group & No. of H'hlds & $\%$ of H'hlds & & No. of H'hlds & $\%$ of H'hlds \\
\hline 1: Immensely Rich & 5 & $1 \cdot 0$ & & 4 & $0 \cdot 4$ \\
2: Very Rich & 6 & $1 \cdot 0$ & & 15 & $1 \cdot 3$ \\
3: Rich & 18 & $3 \cdot 0$ & & 20 & $1 \cdot 8$ \\
4: Above Average & 106 & $17 \cdot 4$ & & 678 & $59 \cdot 4$ \\
5: Average & 116 & $19 \cdot 0$ & & 297 & $26 \cdot 0$ \\
6: Poor & 163 & $26 \cdot 8$ & & 101 & $8 \cdot 8$ \\
7: Very Poor & 195 & $32 \cdot 0$ & & 27 & $2 \cdot 4$ \\
Total & $\mathbf{6 0 9}$ & & $\mathbf{1 , 1 4 2}$ & \\
\hline \hline
\end{tabular}

Source: Loiske (1995) and Participatory ranking exercise with village leaders and executive officers, 2013 .

This table compares all residents in the 199os with all residents in 2013. The difference is highly significant: $\chi^{2}=529 \cdot 21 ; \mathrm{df}=6$.

There are three possible scenarios that could explain this change. First, it is possible that the poor people of 20 years ago have simply left the village. Alternatively the poor families could have got richer. Or there may be a mixture of both factors.

When Brockington revisited the families surveyed by Loiske, he found that few people had left the village. Those that had gone tended to belong to richer families whose wealth lay in livestock. They moved to areas where there was more space for grazing. Instead, the reason why there are more wealthy families is because people who were poor have now become richer. This can be seen in Table III, which shows the same general movement of households out of the poorest categories (in dark grey) and into the middle categories (in light grey).

But this is not a simple story of greater prosperity for all. The actual dynamics are more complicated, and these are shown in Table IV. Here the two columns on the left show where the families were in the early 199os, and the columns on the right show where they were at the time of re-survey. Notice two things about this table. First, it shows that most families from the poorer families category have become richer. Those who started off in the poorest categories $(5,6$ or 7 ) have tended to move up to richer groups. But notice that the families which started off in richer categories 2, 3 and 4 , have tended to get poorer, or stay the same. There are therefore two sets of changes to explain - why have the richer families got poorer, and why are the 
T A B LE I I I.

Change to visited households 1990s-2013 Part 1

\begin{tabular}{lcr}
\hline \hline Wealth Group & 1990 & 2013 \\
\hline 2 & 2 & 0 \\
3 & 5 & 12 \\
4 & 18 & 29 \\
5 & 12 & 24 \\
6 & 21 & 7 \\
7 & 19 & 5 \\
Total & 77 & 77 \\
\hline \hline
\end{tabular}

Source: Loiske (1995) and Brockington's fieldwork, 2013.

This table compares the condition of the sample visited in the 1990 with its condition in 2013 .

poorer families richer? Both issues were discussed in interviews with families and two village discussion groups.

Focus groups and oral histories suggested several driving forces behind the decline of the wealthy. Rich families have become poorer because of illness, because of family troubles (divorce, or the expense of seeking or maintaining a second wife), through taking to drink or simply because they are older and have lost their strength. Rich families appear poorer simply because they are moving through the later stages of life cycles which see them allocate assets to their children. Some once richer families are headed by elderly couples who are simply less able to manage large farms than they were before.

In other cases the decline merely reflects the inadequacy of the categorisation system. Investments in education did not appear in Loiske's original scheme. Yet some of the wealthy families in the village have done just that, investing returns from agriculture, and selling agricultural assets (livestock, tractors), in order to fund their children's training. This means that they appear to be less wealthy than before, but they are compensated by their children being employed as teachers or government officers and benefitting from regular salaries as a result.

With respect to the move out of poverty, four explanations were offered in focus groups and interviews. The most frequently voiced was that people have got richer because they have worked hard at their farming. They have been able to invest in cattle, modern seeds and farm implements. This work has been more rewarding because local terms of trade for farm produce has improved. Table $\mathrm{V}$ shows that crops have generally increased their farm gate prices by between 
TABLE IV.

Change to visited households 1990s-2013 Part 2

\begin{tabular}{|c|c|c|c|c|c|c|}
\hline \multicolumn{2}{|c|}{ Households in 1990 s } & \multicolumn{5}{|c|}{$\begin{array}{l}\text { Wealth distribution in } \\
2013\end{array}$} \\
\hline Original Wealth Group & Number of households in each group & 3 & 4 & 5 & 6 & 7 \\
\hline 2 & 2 & 2 & & & & \\
\hline 3 & 5 & 1 & 2 & 1 & 1 & \\
\hline 4 & 18 & 5 & 4 & 6 & 1 & 2 \\
\hline 5 & 12 & 2 & 5 & 4 & 1 & \\
\hline 6 & 21 & 2 & 12 & 6 & 1 & \\
\hline 7 & 19 & & 6 & 7 & 3 & 3 \\
\hline Total & 77 & 12 & 29 & 24 & 7 & 5 \\
\hline
\end{tabular}

Source: Loiske (1995) and Brockington's fieldwork, 2013.

This table compares the status of households visited in the 1990s with their status in 2013.

$160 \%$ and $300 \%$ in the last 20 years. Moreover, as Table VI shows, some cash crops are now yielding considerably greater returns, relative to maize, than they were in previous years. Whereas two sacks of beans used to be able to purchase three of maize, now they can purchase almost five. 7 Thus families who farm cash crops have been able to secure their subsistence needs more easily and, possibly, generate a surplus. To summarise this point, the villagers we surveyed demonstrated substantial improvements in prosperity, founded upon retention of assets, and improved returns to them (due to crop price increases), as well as growth of assets (herds) and investment in homes and education.

A second cause of poverty that many families reported was alcoholism. Accordingly poverty has declined as some have been able to stop drinking, or, in other cases, children have taken over the farm from alcoholic parents (generally fathers) who merely rented their land out each year for enough money to keep them in drink. Loiske's work shows that this was a serious problem in the 199os. Conversely those poor families who stayed poor during the years of our survey were often unreformed alcoholics.

We cannot tell whether alcoholism was the cause or consequence of poverty. It was probably a mixture of both. We should also note that alcohol sales are often a means by which women (who make and sell alcohol) gain access to money which is controlled by men (who are the main consumers of the drink). Our data do not allow us to comment on the social dynamics of the relative demise of alcoholism. 
TABLE V.

Average farm gate price in Hanang

\begin{tabular}{llrrrrrr}
\hline \hline $\begin{array}{l}\text { Deflation } \\
\text { by }\end{array}$ & $\begin{array}{l}\text { Years } \\
\text { averaged }\end{array}$ & Maize & Beans & Wheat & Potatoes & Sunflowers & $\begin{array}{l}\text { Pigeon } \\
\text { Peas }\end{array}$ \\
\hline Purchasing & $1990-93$ & $34 \cdot 70$ & $5^{6 \cdot 21}$ & $35 \cdot 18$ & $40 \cdot 86$ & $28 \cdot 23$ & $29 \cdot 35$ \\
Power & $2009-12$ & $70 \cdot 74$ & $169 \cdot 69$ & $114 \cdot 62$ & $13^{6} \cdot 84$ & $58 \cdot 46$ & $105 \cdot 10$ \\
Parity & Increase & $204 \%$ & $302 \%$ & $326 \%$ & $335 \%$ & $207 \%$ & $35^{8 \%}$ \\
Consumer & $1990-93$ & 14,135 & 22,958 & 14,340 & 16,683 & 11,538 & 11,997 \\
Price & $2009-12$ & 22,605 & 54,300 & 36,039 & 42,228 & 19,139 & 35,026 \\
Index & Increase & $160 \%$ & $237 \%$ & $251 \%$ & $253 \%$ & $166 \%$ & $292 \%$ \\
\hline \hline
\end{tabular}

Source: Hanang District Council Records.

The point is simply that fewer families in this survey now suffer as a result of it than was the case before.

A third possibility that could explain greater prosperity is that local exploitation of poor families by rich families in the village has decreased. Loiske's work and local history makes clear that some of the wealthy farmers in the 1990 (the yeomanry families that the British had supported) were able to rent land while paying poor families little money for it. They controlled the tractors required to plough up large areas of land, and particularly some of the heavier clay soils which dominated some families' farms. Now, however, as more people have ploughs, as oxen and tractor ownership has broadened, it is harder for the richer families to dictate terms. Investment in assets has broadened the productive base of the village as a whole.

Finally, in a number of ways, some of the tasks that women have undertaken have become, relatively speaking, easier. There are now readily accessible diesel-powered mills to grind corn (as opposed to grinding by hand using stones) and water is more easily available at village standpipes. There are more health clinics, which was reported in the focus groups to have improved maternal health. All these measures will have enabled women to put more of their time into more remunerative work. Infrastructural improvements in their lives may have led to more productive use of agricultural assets.

Our data do not allow us to determine which of the causes of change described here is most important. Our sample size is not large 
TABLE VI.

Relative price of $100 \mathrm{~kg}$ of maize to $100 \mathrm{~kg}$ of other crops in Hanang

\begin{tabular}{lccccc}
\hline \hline Years averaged & Beans & Wheat & Potatoes & Sunflower & Pigeon peas \\
\hline $1990-93$ & $162 \%$ & $101 \%$ & $118 \%$ & $82 \%$ & $85 \%$ \\
$2009-12$ & $240 \%$ & $159 \%$ & $187 \%$ & $85 \%$ & $155 \%$ \\
\hline \hline
\end{tabular}

Source: Hanang District Council Records. Prices have been deflated by the Consumer Price Index (CPI).

enough, nor the measurement of assets precise enough, for that sort of modelling and correlation. However, the value of this sort of research is to suggest hypotheses for testing in larger studies, and useful avenues of enquiry that may be pursued further, as well as suggesting methodological insights. In that spirit we discuss four challenges that this research poses.

The first challenge is the relationship between rural economies and national level GDP. What are we to make of the fact that rural prosperity in Gitting has risen alongside national GDP growth? Does this suggest that rural economies are well tied to national economic growth? Could counting assets reveal unrecognised growth?

We feel such speculation is premature. We believe that exploring assets makes it possible to tell more stories about the nature of economic and social dynamics in rural areas. But we do not think that the findings from Gitting necessarily prove that a rising national GDP has reduced poverty in this village. That assumes that national GDP figures and local incidences of rural prosperity or poverty are well connected in the first place.

It is, however, possible that GDP figures are only weakly related to livelihoods in remote rural areas. We know that GDP has risen as a result mainly of growth in the manufacturing, mining and service sectors. Agriculture contributes only 30\% of GDP (World Bank 2015). Thus, depending on the composition of GDP growth, it could be misleading to expect a good relationship between GDP growth and rural livelihoods if the change in GDP does not derive from agriculture.

We must also recall that the statistics used to estimate agricultural contributions may well be weak and unreliable (cf. Jerven 2011). They simply do not capture much of the activity in the informal sector which dominates life in rural Tanzania. Edwards reports the wellknown case of the drought of late 2005 in Tanzania, the worst for 20 
years, in which food crop production is estimated to have declined by ${ }^{10-15} \%$ in 2006. Nevertheless, government statistics show that agricultural GDP grew by $4 \cdot 1 \%$ in that year (Edwards 2014: $244-5$ ). Official figures for the agricultural component of GDP may not be accurate enough to explain village-level growth.

Thus it might be possible for the agricultural sector to thrive, and for the broader economy not to and vice versa. If, in fact, most farmers contribute relatively little to the crop sales measured in GDP calculations then it is likely that their own livelihood dynamics could be quite separate from the changes suggested by GDP. As Dercon \& Gollin (2014: 483 ) have observed, poor spatial connectivity can increase the heterogeneity of countries' agricultural sectors and render some areas effectively closed economies.

Viewed thus we should not be surprised that GDP increases seem poorly reflected in the consumption patterns of the rural poor, as Mashindano and others complain. Nor in fact should we read too much into the fortunes of Gitting (as measured in assets) appearing to match those of the nation. Rather than trying to explore the connections between the two scales of activity (village and nation), we would require separate sets of explanation for change in each.

The second surprising result from this work is the proposition that people could have become more prosperous as a result of greater agricultural activity and higher crop prices (shown in Tables V and VI). This is surprising because most accounts of Tanzanian agriculture emphasise its low productivity and stasis (Gollin \& Goyal 2017). Investigations suggest that most rural households are net consumers, not producers, of food and therefore any increase in crop prices should make most rural people poorer. Jayne and colleagues have shown that for numerous countries in the region, most agricultural surplus is produced by a small minority of relatively large farms and prosperous farmers (Jayne et al. 2010). We have reproduced their findings in Table VII and supplemented it with Tanzanian data from the Living Standards Measurement Study (LSMS). The Tanzanian data show the same levels of inequality as other countries, and suggest the same basic point. Because most rural households in Tanzania buy more food than they sell, increasing crop prices should make most families poorer not richer.

Similarly, Bryngelsson and colleagues have expanded Jayne et al.'s analysis using the 2004 KDHS and by including all foods, and not just the main staples (Bryngelsson et al. 2012). They found that $87 \%$ of the rural population are net buyers of food. Smaller farmers both produce less, and are often required to sell any surplus when the price 
TAB LE VII.

Distribution of farming activity in selected African countries

\begin{tabular}{|c|c|c|c|c|c|}
\hline \multirow[b]{2}{*}{ Country \& Year of Survey } & \multirow[b]{2}{*}{ Attribute: Mean } & \multicolumn{4}{|c|}{ Quartiles of land ownership per capita } \\
\hline & & Lowest quartile & Second quartile & Third quartile & Highest quartile \\
\hline \multirow{2}{*}{$\begin{array}{l}\text { Kenya } \\
2003 / 04\end{array}$} & Farm Size & $0 \cdot 5^{8}$ & $1 \cdot 25$ & $2 \cdot 12$ & $5 \cdot 91$ \\
\hline & Crop Sales $(\$)$ & 261 & 672 & 979 & 15 OO \\
\hline \multirow{2}{*}{$\begin{array}{l}\text { Ethiopia } \\
1996\end{array}$} & Farm Size & $0 \cdot 2$ & $0 \cdot 67$ & $1 \cdot 15$ & $2 \cdot 5^{8}$ \\
\hline & Crop Sales $(\$)$ & $4^{8 \cdot 3}$ & 118 & 173 & 380 \\
\hline \multirow{2}{*}{$\begin{array}{l}\text { Rwanda } \\
2001\end{array}$} & Farm Size & $0 \cdot 32$ & $0 \cdot 63$ & 1 & $1 \cdot 82$ \\
\hline & Crop Sales $(\$)$ & $5^{6 \cdot 3}$ & $74 \cdot 5$ & 120 & 280 \\
\hline \multirow{2}{*}{$\begin{array}{l}\text { Mozambique } \\
2002\end{array}$} & Farm Size & $0 \cdot 53$ & $1 \cdot 2$ & $1 \cdot 76$ & $3 \cdot 14$ \\
\hline & Crop Sales $(\$)$ & $11 \cdot 8$ & $26 \cdot 1$ & $34^{\cdot 1}$ & $61 \cdot 4$ \\
\hline \multirow{2}{*}{$\begin{array}{l}\text { Zambia } \\
2000\end{array}$} & Farm Size & $0 \cdot 71$ & $1 \cdot 6$ & $2 \cdot 75$ & $5 \cdot 81$ \\
\hline & Crop Sales $(\$)$ & $42 \cdot 7$ & $77 \cdot 3$ & 109 & $14^{8}$ \\
\hline \multirow{3}{*}{$\begin{array}{l}\text { Tanzania } \\
2010 / 11\end{array}$} & Farm Size & $1 \cdot 05$ & $2 \cdot 39$ & $3 \cdot 96$ & $10 \cdot 4^{6}$ \\
\hline & Crop Sales $(\$)$ & 24 & 64 & 113 & 239 \\
\hline & Livestock Sales $(\$)$ & 64 & $5^{8}$ & $4^{2}$ & 76 \\
\hline
\end{tabular}

Source: Jayne et al. (2010) (Table II) and LSMS 2011 data (for Tanzania). Tanzanian data include all households, urban or rural, who farmed land. All sales figures have been converted to 2011 US\$, using the CPI deflator available at $<$ http://www.measuringworth.com>, accessed 9.1.2018. 
is particularly low. Therefore, if this was the case in Gitting, then the increased prosperity we record in assets will have happened despite food price increases, not because of them. Higher food prices would not make the rural poor richer, it would add to their troubles.

But we must be careful with such national-scale generalisations of rural economies. Analyses of their dynamics must allow for more complexity; as Dercon and Gollin put it, '[t] he central fact of agriculture in sub-Saharan Africa is enormous heterogeneity' (Dercon \& Gollin 2014: 483), and this includes within-country heterogeneity (Dercon \& Gollin 2014: 485). Kagera, from where Bryngelsson and colleagues' data came, is a major coffee growing area, which has a particular dynamic reflecting changes in the coffee economy, and a long-term decline in coffee prices. In Hanang, which depends on cultivating wheat, potatoes, maize and beans, there will be a different history.

We also have to factor in livestock, whose economic contributions have been consistently under-estimated (as in Behnke's work reported above). In Tanzania, livestock sales are more important than crop sales for households with smaller farms (Table VII, bottom row). This reflects the fact that many pastoral families may not cultivate much land. Their poor crop sales are not a good indication of the returns they experience from participating in the rural economy. They participate through selling livestock and milk (Brockington 2001).

In addition to the complex geography of rural economies, the dynamics of economies over time will have variable impacts upon poorer households. Bryngelsson and colleagues argue that while food price rises in the short term may be harmful to households who spend most of their money on food, and who are net purchasers of food, in the longer term the consequences are more complicated. Higher food prices can lead to higher rural wages and to increased agricultural productivity, such that more families become net producers not net consumers.

Finally, it is important to consider what variety of foods households produce and the extent of their dependence on purchased produce. This variety, the diverse changes in costs of each food relative to others, and the multiple margins on which consumption can be adjusted led Dercon \& Gollin $(2014: 481)$ to conclude that the welfare implications of food price changes are very complicated. Bryngelsson and colleagues emphasise that households which produce a significant proportion of their own food can benefit from both increasing and decreasing food prices. They explain this as follows: 
by altering their consumption basket they can ... increase their welfare ... If food prices go down, they can shift towards better quality food or more food consumption at the expense of a relatively small decrease in non-food consumption. If food prices go up, on the other hand, they can similarly shift towards more non-food consumption at the cost of a relatively small decrease in food quality or quantity. These new options should increase their total welfare. (Bryngelsson et al. 2012: 131)

This point matters because LSMS data for Tanzania show that, with respect to staples, most families, most of the time, are net producers, not net buyers of their staple food (Table VIII). ${ }^{8}$ Sixty-six per cent of rural residents in this survey enjoy surpluses almost all year round. They could belong to those households who produce significant proportions of their own food and thus benefit from all food price changes, both increases and decreases.

It is therefore possible to explain how smallholders could prosper from small farms and rising food prices. Nevertheless, given the starkness of Jayne and colleagues' findings, the prosperity we have recorded in Gitting remains surprising. Comparative data that would allow us to compare our finding with others are few. Our suggestions do not fly in the face of hundreds of studies because adequate survey data simply do not exist to provide them. We venture it therefore as a possibility which requires more investigation.

The third surprise is that asset accumulation seems to have reversed processes of rural differentiation. Studies from elsewhere in Tanzania show that wealthy rural families are able to maintain their wealth through exploitative labour practices, or through using their wealth to provide political influence to facilitate land acquisition (Mueller 2011; Greco 2015). Gitting complicates this picture. Exploitative land hiring arrangements have declined, as have the extremes of inequality that British support had fostered. In part this may be due to the fact that we considered a broader bundle of assets than just land. In part it may be because land was still relatively plentiful and so it was harder for inequalities to grow and deepen. Unworked land was still cheaply available during Brockington's fieldwork within a day's bicycle ride of Gitting. Hardworking, but poor, families could thus accumulate assets through agricultural activity. The class dynamics of Tanzanian villages are complex. The form and level of inequality that are found will vary according to the measurements used to determine prosperity and poverty, the distribution of the means of production, and the accessibility of the different engines of productivity (land, labour, credit, productive assets). 
TABLE VIII.

Net production and purchase of staple through the year

\begin{tabular}{|c|c|c|c|c|c|c|c|c|c|c|c|c|c|}
\hline Land quartile & $\mathrm{J}$ & $\mathrm{F}$ & M & A & M & $\mathrm{J}$ & $\mathrm{J}$ & A & S & $\mathrm{O}$ & $\mathrm{N}$ & $\mathrm{D}$ & $\%$ of Rural Ppn \\
\hline No land & $-6 \cdot 8$ & $-9 \cdot 8$ & $-7 \cdot 7$ & $-8 \cdot 3$ & $-8 \cdot 7$ & $-8 \cdot 8$ & $-6 \cdot 8$ & $-5 \cdot 6$ & $-2 \cdot 5$ & $-8 \cdot 8$ & $-7 \cdot 2$ & $-6 \cdot 5$ & 16 \\
\hline Lowest & $-2 \cdot 4$ & $-4 \cdot 2$ & $-5 \cdot 2$ & $-3 \cdot 0$ & $7 \cdot 9$ & $2 \cdot \mathrm{O}$ & $2 \cdot 5$ & $1 \cdot 9$ & $11 \cdot 0$ & $-1 \cdot 5$ & $-3 \cdot 8$ & $4 \cdot 1$ & 17 \\
\hline Second & $-0 \cdot 1$ & $4 \cdot 0$ & $6 \cdot 3$ & $21 \cdot 5$ & $13 \cdot 1$ & $16 \cdot 5$ & $12 \cdot 6$ & $3 \cdot 5$ & $12 \cdot 3$ & $6 \cdot 0$ & $2 \cdot 9$ & $6 \cdot 0$ & 18 \\
\hline Third & $1 \cdot 4$ & $2 \cdot 6$ & $8 \cdot 0$ & $20 \cdot 7$ & $16 \cdot 3$ & $12 \cdot 4$ & $9 \cdot 5$ & $9 \cdot 2$ & $12 \cdot 8$ & $13 \cdot 1$ & $7 \cdot 3$ & $8 \cdot 2$ & 22 \\
\hline Richest & $5 \cdot 3$ & $9 \cdot 6$ & $16 \cdot 0$ & $17 \cdot 6$ & $17 \cdot 4$ & $15 \cdot 9$ & $9 \cdot 1$ & $10 \cdot 0$ & $9 \cdot 2$ & $7 \cdot 6$ & $7 \cdot 8$ & $4 \cdot 2$ & 26 \\
\hline Households visited & 216 & 210 & 177 & 179 & 241 & 192 & 229 & 275 & 126 & 186 & 307 & 245 & \\
\hline
\end{tabular}

Source: LSMS 2011 data. Table includes all rural households and shows net weight of staple produced (+) or purchased (-) in the week sampled. Shaded cells indicate net deficit of staple food. 
Finally, there is the question of the gender dynamics of the increasing prosperity we have recorded. Our study has focused on families and domestic units, which necessarily obscures the gendered distribution of benefits within them. Given that most of the domestic units in this area are led by men, who will ostensibly own many of the assets, in some respects we have documented most clearly improving male fortunes rather than general fortunes. As one anonymous reviewer of this article commented, 'some households may have acquired more assets and improved on them because of the labour and investment of female members who are not entitled to dispose of them or use them for collateral'.

There is much truth in that observation, and, at the same time, we must recognise that male control over these assets is not a given. It is contested, and husbands and fathers can lose those arguments. In some instances families were able to prosper because (male) children and their mothers conspired against their fathers to stop them renting out family land in order to feed a drinking habit. In other instances family disputes are played out in competing attempts to control assets. Women, for example, will own and breed pigs, whose sale they control. Their husbands will try and usurp control of the animals, and on occasion fail to do so.

Nevertheless, the point remains that if our research has shown the importance of studying change in assets, then it has also highlighted the need to explore how rural men and women separately use farm and off-farm income to invest in assets. The way in which women invest income in land, improved equipment, livestock and the education of children is not well described in the literature. This will explain, in part, why the changing fortunes of some rural families are still hidden to some researchers, economists and government planners.

It is premature to enthusiastically welcome Tanzania's recent decades of economic growth if that growth has not included the poor. It is difficult to see what purpose growth serves if it is not inclusive. Equally, before condemning its lack of connection to the rural poor, we have to know how to measure the benefits (or otherwise) that economic growth might have. Current misgivings about Tanzanian economic growth excluding the poor have been based primarily on measures of consumption. This is an important aspect of poverty, as it shows in a basic material 
sense that the economic growth the rest of the country enjoys is not well shared. But nevertheless this measure overlooks change in assets. We cannot conclude from the stasis in poverty lines that economic growth is not assisting households to move out of poverty (more broadly defined).

The findings from this article suggest that it is important to explore change in assets, as well as change in consumption, if we are to understand how inclusive economic growth is for the rural poor (cf. Shaffer 2013a). The families described in this village have experienced a remarkable change of fortunes in the last 20 years, as measured by their assets. Measures of household prosperity which ignore assets will be unable to capture the sorts of dynamics described in this survey.

The data presented here suggest that determining the inclusivity, or otherwise, of economic growth in the absence of understanding trends in assets is premature. Current poverty lines rely solely on consumption indices of a restricted range of goods. But understanding poverty dynamics during times of economic growth requires incorporating a notion of the dynamics of asset use and ownership. Rather than asking why growth is not inclusive (as recommended by Mashindano \& Shepherd 2013), it is important first to ask how change in assets is related to change in consumption. Unfortunately, the historical data presented here do not allow us to explore that relationship. That is a task for ongoing analyses of panel data.

The case is taken from one Tanzanian village, which is well endowed with agricultural resources and well-placed to benefit from improvements to the agricultural economy. Care is required when extrapolating from this case study. We are not asserting from this case that most rural Tanzanians have in fact benefitted from 20 years of economic growth. We can, however, suggest that it is possible for many rural Tanzanians to have benefitted thus. The challenge now is to identify how to explore long-term trends in rural asset dynamics over the last 20 years in rural Tanzania.9 By extending this technique to other areas of Tanzania, with different agro-ecological conditions, different histories, and different affinities to commercial agriculture we could build up a richer picture of change across the rural economy during a period of GDP growth. By exploring the dynamics of investment in assets and changing control over them, we could understand better how changing asset portfolios contributes to the well-being of men and women differently. Through such work we hope to contribute to a rich understanding of the nature and consequences of economic growth to locally meaningful understandings of wealth, poverty and prosperity. 


\section{NOTES}

1. The detailed analyses are not all depressing. There is clear evidence that the growth in education is very pro-poor, with enrolment of the poorest quintile increasing from $47 \%$ to $78 \%$ (Hoogeveen \& Ruhinduka 2009).

2. It is unfortunately not clear what large durable items have been omitted in the calculations of poverty lines. The accompanying documentation does not list items, nor does it specify the precise criteria by which they are included or excluded. We only learn that '[o] utliers were identified using two criteria: that the actual expenditure per capita on that item/category was high, and that the budget share of the item was also high for that household. The latter criterion helps ensure that wealthy households with genuinely high expenditure on a range of items are not mistakenly identified as outliers. Outlying expenditure values for a given item were replaced with the mean expenditure calculated across all households' (United Republic of Tanzania 20o9: 78). An important project for future research would be to consider precisely what forms of investment in asset, for which sorts of families, are excluded by poverty line calculations.

3. These calculations of the worth of livestock reiterates long-recognised problems with the modern state's understandings of the economics of pastoral societies (Behnke 1985; Behnke \& Scoones 1993; Homewood 2008).

4. Kilwa Focus Group 22.2.2017.

5. Gitting was subsequently split, for administrative purposes, into two contiguous villages named Gitting and Gocho. For simplicity's sake we shall simply refer to 'Gitting' in the text.

6. This household list included all families in the village but omitted itinerant agricultural labourers from the neighbouring region of Singida who were given temporary accommodation on farms. The omission is important because it means that this survey and its long-term findings are no guide to the changing fortune of itinerant labourers. It is a guide to the fortunes of land-owning farmers.

7. These prices and terms of trade have not been altered by reduced transportation costs due to road improvements. Road links to the main towns of Babati and Arusha have been generally unchanged for the period under study, half being paved, and the other half unmetalled. The tarmac road between Arusha and Singida (which passes near Gitting) was only completed in 2012.

8. The consumption data in the LSMS survey are collected for only one week. We have taken that weekly consumption to be typical of the month from which it was collected.

9. The task of locating suitable surveys, from which longitudinal panel data could be reconstructed, has already begun in a project funded by the ESRC and DfID. For more information see $<$ http://livelihoodchangeta.wixsite.com/tanzania/project-summary $>$.

\section{R E F E R E N C E S}

Adam, C.S., P. Collier \& B. Ndulu. 2017. Tanzania: The Path to Prosperity. Oxford: Oxford University Press.

Adato, M., F. Lund \& P. Mhlongo. 2007. 'Methodological innovations in research on the dynamics of poverty: a longitudinal study in KwaZulu-Natal, South Africa', World Development 35: 247-63.

Arndt, C., V. Leyaro, K. Mahrt \& F. Tarp. 2017. 'Growth and poverty. a pragmatic assessment and future prospects', in C.S. Adam, P. Collier \& B. Ndulu, eds. Tanzania: The Path to Prosperity. Oxford: Oxford University Press. doi: 10.1093/acprof:oso/978019870481 2.001.0oo1

Barrett, C. 2011 . Assisting the Escape from Persistent Ultra-poverty in Rural Africa. Stanford Symposium Series on Global Food Policy and Food Security in the 21 st Century. Stanford, CA: Stanford University.

Baulch, B. 201 1. Why Poverty Persists. Poverty Dynamics in Asia and Africa. Cheltenham: Edward Elgar.

Baulch, B. \& J. Hoddinott. 20oo. 'Economic mobility and poverty dynamics in developing countries', Journal of Development Studies 36: 1-24.

Beegle, K., J. De Weerdt \& S. Dercon. 201 1. 'Migration and economic mobility in Tanzania: evidence from a tracking survey', Review of Economics and Statistics 93: 1010-33.

Behnke, R.H. 1985 . 'Measuring the benefits of subsistence versus commercial livestock production in Africa', Agricultural Systems 162.

Behnke, R.H. 2010. 'The contribution of livestock to the economies of IGAD MEMBER states: study findings, application of the methodology in Ethiopia and Recommendations for Further Work'. IGAD LPI Working Paper No. 02-10. Addis Ababa: IGAD LPI. 
Behnke, R.H. \& F. Metaferia. 2011. 'The contribution of livestock to the Ethiopian economy - Part II'. IGAD LPI Working Paper No. o2-1 1. Addis Ababa: IGAD LPI.

Behnke, R.H. \& D. Muthami. 2011. 'The contribution of livestock to the Kenyan economy'. IGAD LPI Working Paper No. o3-11. Addis Ababa: IGAD LPI.

Behnke, R.H. \& M. Nakirya. 201 2. 'The contribution of livestock to the Ugandan economy'. IGAD LPI Working Paper No. 02-12. Addis Ababa: IGAD LPI.

Behnke, R.H. \& H.M. Osman. 201 2. 'The contribution of livestock to the Sudan economy'. IGAD LPI Working Paper No. o1-12. Addis Ababa: IGAD LPI.

Behnke, R.H. \& I. Scoones. 1993. 'Rethinking Range Ecology: implications for rangeland management in Africa', in R.H. Behnke, I. Scoones \& C. Kerven, eds. Range Ecology at Disequilibrium: new models of natural variability and pastoral adaptation in African savannas. London: ODI, 1-3o.

Benjaminsen, T.A. \& I. Bryceson. 2012. 'Conservation, green/blue grabbing and accumulation by dispossession in Tanzania', Journal of Peasant Studies 39: $335^{-} 55^{\text {. }}$

Borras, S.J., R. Hall, I. Scoones, B. White \& W. Wolford. 2011. 'Towards a better understanding of global land grabbing: an editorial introduction', Journal of Peasant Studies 38: 209-16.

Brockington, D. 2001. 'Women's income and livelihood strategies of dispossessed pastoralists: the case of Mkomazi Game Reserve', Human Ecology 29: 307-38.

Brockington, D., S. Randall \& E. Coast. 2017 . 'Households, domestic units and assets. methodological challenges to longitudinal studies of poverty dynamics'. Unpublished ms.

Bryngelsson, D.K., A. Åhlén, C. Azar \& U.M. Persson. 201 2. 'The effect of food-price movements on African households', International Journal of Agricultural Resources, Governance and Ecology 9: $121-46$.

Carter, M.R. \& T.J. Lybbert. 201 2. 'Consumption versus asset smoothing: testing the implications of poverty trap theory in Burkina Faso', Journal of Development Economics 99: 255-64.

Chuhan-Pole, P. \& M. Angwafo. 2011. Yes Africa Can: success stories from a dynamic continent. Washington, DC: The World Bank.

Dercon, S. 2006. 'Economic reform, growth and the poor: evidence from rural Ethiopia', Journal of Development Economics 81: 1-24.

Dercon, S. \& D. Gollin. 2014. 'Agriculture in African development: theories and strategies', Annual Review of Resource Economics 6: 471-92.

Dercon, S. \& J.S. Shapiro. 2007. 'Moving on, staying behind, getting lost: lessons on poverty mobility from longitudinal data'. GPRG Working Paper Series 75. Oxford: Global Poverty Research Group.

Dercon, S., D.O. Gilligan, J. Hoddinott \& T. Woldehanna. 20o9. 'The impact of agricultural extension and roads on poverty and consumption growth in fifteen Ethiopian villages', American Journal of Agricultural Economics 91: 1007-21.

De Waal, A. 1989. Famine that Kills: Darfur, Sudan, 1984-1985. Oxford: Clarendon Press.

De Weerdt, J. 2010 . 'Moving out of poverty in Tanzania: evidence from Kagera', Journal of Development Studies 46: $331-49$.

Edwards, S. 2014. Toxic Aid: economic collapse and recovery in Tanzania. Oxford: Oxford University Press.

Fairhead, J., M. Leach \& I. Scoones. 2012. 'Green grabbing: a new appropriation of nature?', Journal of Peasant Studies 39: 237-61.

Gardner, B. 2012. 'Tourism and the politics of the global land grab in Tanzania: markets, appropriation and recognition', Journal of Peasant Studies 39: 377-402.

Gollin, D. \& R. Goyal. 201 7. 'Agricultural transformation in Tanzania: linking rural to urban through domestic value chains', in C.S. Adam, P. Collier \& B. Ndulu, eds. Tanzania: the path to prosperity. Oxford: Oxford University Press. doi: 10.1093/acprof:oso/978019870481 2.003.0oo6.

Greco, E. 2015. 'Landlords in the making: class dynamics of the land grab in Mbarali, Tanzania', Review of African Political Economy 42: $225^{-44}$.

Guyer, J. 1981. 'Household and community in African studies', African Studies Review 24: 81-137.

Harttgen, K., S. Klasen \& S. Vollmer. 2013. 'An African growth miracle? Or: what do asset indices tell us about trends in economic performance?', Review of Income and Wealth 59: s37-61.

Higgins, K. \& L. Da Corta. 2013. 'Understanding structural influences on poverty dynamics in Tanzania - using a relational life history Q-squared approach', in F. Kessy, O. Mashindano, A. Shepherd \& L. Scott, eds. Translating Growth Into Poverty Reduction: beyond the numbers. Dar es Salaam: Mkuki na Nyota, 11-26.

Homewood, K.M. 2008. Ecology of African Pastoralist Societies. Athens, OH: Ohio University Press.

Hoogeveen, J. \& R. Ruhinduka. 20o9. 'Lost in transition? Income poverty reduction in Tanzania since 2001'. Paper Prepared for the Research and Analysis Working Group.

Howe, G. \& A. McKay. 2007. 'Combining quantitative and qualitative methods in assessing chronic poverty: the case of Rwanda', World Development 35: 197-211. 
Jayne, T.S., D. Mather \& E. Mghenyi. 2010. 'Principal challenges confronting smallholder agriculture in Sub-Saharan Africa', World Development 38: 1384-98.

Jerven, M. 2011. 'Growth, stagnation or retrogression? On the accuracy of economic observations, Tanzania, 1961-2001', Journal of African Economies 20: 377-94.

Johnston, D. \& A. Abreu. 2016. 'The asset debates: how (not) to use asset indices to measure wellbeing and the middle class in Africa', African Affairs 115: 399-418.

Krishna, A. 2006. 'Pathways out of and into poverty in 36 villages of Andhra Pradesh, India', World Development 34: 271-88.

Krishna, A. 2010. One Illness Away. Why People Become Poor and How They Escape Poverty. Oxford: Oxford University Press.

Krishna, A., P. Kristjanson, M. Radeny \& W. Nindo. 2004. 'Escaping poverty and becoming poor in twenty Kenyan villages', Journal of Human Development 5: 21 1-26.

Lawson, D., A. McKay \& J. Okidi. 2003. 'Poverty persistence and transitions in Uganda: a combined qualitative and quantitative analysis'. Working Paper 38 . Manchester: University of Manchester, Chronic Poverty Research Centre.

Loiske, V.-M. 1995. The Village that Vanished: the roots of erosion in a Tanzanian village. Stockholm: University of Stockholm.

Mashindano, O. \& A. Shepherd A. 2013. 'Introduction: translating growth into poverty reduction', in F. Kessy, O. Mashindano, A. Shepherd \& L. Scott L., eds. Translating Growth Into Poverty Reduction: beyond the numbers. Dar es Salaam: Mkuki na Nyota, 1-9.

Mashindano, O., K. Kayunze, L. Da Corta \& F. Maro. 2013. 'Growth without poverty reduction in Tanzania - reasons for the mismatch', in F. Kessy, O. Mashindano, A. Shepherd \& L. Scott L., eds. Translating Growth Into Poverty Reduction: beyond the numbers. Dar es Salaam: Mkuki na Nyota, $122-41$.

Meinzen-Dick, R., N. Johnson, A. Quisumbing, J. Njuki, J. Behrman, D. Rubin, A. Peterman \& E. Waithanji. 2011. 'Gender, assets, and agricultural development programs: a conceptual framework'. CAPRi Working Paper No. 99.

Moock, J.L. 1986. Understanding Africa's Rural Households and Farming Systems. Boulder, CO: Westview Press.

Mueller, B.E.T. 2011. 'The agrarian question in Tanzania: using new evidence to reconcile an old debate', Review of African Political Economy 38: 23-42.

Nord, R., Y. Sobolev, D. Dunn, A. Hajdenberg, N. Hobdari, S. Maziad \& S. Roudet. 2oog. Tanzania: the story of an African transition. Washington, DC: IMF.

Radelet, S. 2010. Emerging Africa. How I 7 Countries Are Leading the Way. Washington, DC: Centre for Global Development.

Raikes, P. 1978. 'Rural differentiation and class formation in Tanzania', Journal of Peasant Studies 5 : $285-325$.

Randall, S. \& E. Coast. 2015. 'Poverty in African households: the limits of survey and census representations', Journal of Development Studies $5^{1:} 162-77$.

Randall, S., E. Coast \& T. Leone. 2011 . 'Cultural constructions of the concept of household in sample surveys', Population Studies 65: 21 -29.

Robinson, D.O., M. Gaertner \& C. Papageorgiou. 2011. 'Tanzania: growth acceleration and increased public spending with macroeconomic stability', in P. Chuhan-Pole \& M. Angwafo, eds. Yes Africa Can: success stories from a dynamic continent. Washington, DC: The World Bank, $21-49$.

Sahn, D.E. \& D.C. Stifel. 20oo. 'Poverty comparisons over time and across countries in Africa', World Development 28: $2123^{-5} 5$.

Scott, L. 2010. 'Giving Assets: an effective approach for reducing vulnerability and building livelihoods? The case of the Chars Livelihoods Programme', PhD, Manchester University.

Shaffer, P. 201 za. Q-Squared: combining qualitative and quantitative approaches to poverty analysis. Oxford: Oxford University Press.

Shaffer, P. 2013b. "Ten years of "Q-squared": implications for understanding and explaining poverty', World Development 45: 269-85.

Snyder, K. 2005. The Iraqw of Tanzania: negotiating rural development. Boulder, CO: Westview Press.

United Republic of Tanzania. 2009. 'Household Budget Survey 2007. Main Report'. Dar es Salaam: National Bureau of Statistics.

World Bank. 2015. Tanzania Mainland Poverty Assessment. Washington, DC: World Bank.

Young, A. 201 2. 'The African growth miracle', Journal of Political Economy 120: 696-739. 